University of Windsor

Scholarship at UWindsor

Spring 2016

\title{
Heredity in the Epigenetic Era: Are We Facing a Politics of Reproductive Obligations?
}

\author{
Michael J. Crawford \\ University of Windsor
}

Follow this and additional works at: https://scholar.uwindsor.ca/biologypub

Part of the Biology Commons, Civil Rights and Discrimination Commons, Developmental Biology Commons, Genetics Commons, Health Law and Policy Commons, Human Rights Law Commons, Law and Society Commons, Obstetrics and Gynecology Commons, and the Sexuality and the Law Commons

\section{Recommended Citation}

Crawford, Michael J., "Heredity in the Epigenetic Era: Are We Facing a Politics of Reproductive Obligations?" (2016). Study of Time: Time and Trace, 15, 235-255.

https://scholar.uwindsor.ca/biologypub/42

This Contribution to Book is brought to you for free and open access by the Department of Biological Sciences at Scholarship at UWindsor. It has been accepted for inclusion in Biological Sciences Publications by an authorized administrator of Scholarship at UWindsor. For more information, please contact scholarship@uwindsor.ca. 


\title{
Heredity in the epigenetic era: are we facing a politics of reproductive obligations?
}

\author{
Forthcoming in: Study of Time Vol 15: Time and Trace. Ostovich, S \& Gross, S. \\ Eds. Brill Academic Publishers, Leiden. \\ "The amazing thing about mammalian development is not that it sometimes goes wrong, \\ but that it ever succeeds." (van Heyningen 2000)
}

\begin{abstract}
Recent research in the emerging field of epigenetics has implications with the potential to re-ignite acrimony in the discourse of reproductive rights, medical ethics, and the role of the state in our homes and in our lives. For scientists, epigenetics has profoundly realigned our understanding of heredity: epigenetics provides a mechanism through which the environmental challenges met in one generation can be inscribed and transmitted to future offspring. Although both genetic parents have the potential to transmit heritable epigenetic changes to their offspring, mothers have a particularly potent effect because nutrition in the uterine environment can exert a supplemental effect upon the epigenetic imprint of her offspring, and potentially, upon subsequent generations. Moreover, parental care post partum may have generational consequences that are more than just social. Unless discussants have a nuanced understanding of basic epigenetics, women could suffer a disproportionate burden of the obligation to promote fetal, neonatal, and trans-generational health. Drawing upon past patterns of discourse, ethics, and legislation in reproductive rights, I will briefly list some of the challenges and temptations that we will be facing at the individual, familial, social, and legislative levels.
\end{abstract}

\section{Keywords:}


heredity, epigenetics, law, social justice, environmental justice, diet, health costs, ethics, reproductive politics 


\section{Introduction}

"The apple does not fall far from the tree," goes the famous adage. The legacy of our ancestors is transmitted to us in the form of genes, cultural/social memes, the built and the altered "natural" environments. We in turn, modify and then transmit these traces of our existence to our descendants. Until recently, debate has centered on the extent to which our behavior, health, etc., are the product of our genes or the social and physical environment that we inhabit. Intelligent observers would intuit that a combination of the two - nature and nurture - is what helps us to develop into such amazingly complex, creative, and resilient organisms. The surprise is that there is now a mechanism linking the two: epigenetics is an emerging field of study that is requiring biologists to reassess their fundamental understanding of inheritance. It is a field that clarifies how the environment and our experiences biochemically alter the way in which our genes behave without altering the sequence of the genes themselves. Epigenetics inscribes an imprint that is both malleable and heritable - in a real sense, it can record critical experiences of our environment and pass them on to the next generation. Lamarck would have been pleased!

Epigenetic imprinting is altered by diet, toxins, drugs, even emotional and social experiences, to name but a few. It affects us at the genetic, cellular, and organismal levels; however, not all imprints are universally applied throughout a body. Some remain cell-type specific, and it is likely that only a few are applied to the sex cells for transmission to prospective offspring. For example, there are even imprints that are gender-specific: differentially imparted by parents and that play a role in regulating fetal size among other things (Moore and Haig 1991, Wilkins and Haig 2003). This varied and sometimes patchy expression of epigenetic imprints makes the phenomenon difficult to study since it is not likely that a blood test will tell you how all other cells in the body are imprinted since the cells that are imprinted may not be circulating. It also makes it hard to predict which imprints are liable to transmit across generations, although some clearly do. 
Nevertheless, an emerging picture indicates that how our ancestors lived and how we conduct our own lives have the potential to give us concern for longer term effects. Imprinting manifests in a subtle way insofar as individuals are concerned, but in aggregate, at the demographic level, the full implications become clear. Without doubt or exaggeration, epigenetics is poised to challenge us in a profound way with respect to medical, ethical, legal, and social values. My agenda will be to define epigenetics, to show how it affects us, and then to suggest how this emerging field could, if not carefully examined, level an unfair burden upon women. The reasons for my concern relate to the way that reproductive ethics and debate have roiled in many jurisdictions since Roe versus Wade. Because human epigenetics studies have predominantly examined the effects of maternally transmitted changes, there is a danger that elements of the biology will be selectively deployed to force an agenda. This representational bias in the literature belies compelling studies that reveal paternal effects, as well as the studies in rodents that are more gender-balanced.

\section{The Mechanics of Epigenetic Imprinting}

So what is epigenetic imprinting? Chromosomes comprise more than just the DNA sequences that spell out our genes: many structural proteins and RNA molecules contribute to give chromosomes their structure. When we look at magnified pictures of

chromosomes, their banded appearance reflects different densities of packing. Alternative constellations of proteins and RNA molecules can be recruited to implement these packaging differences, and these differences in turn regulate accessibility of genes to factors that turn them on or off. Typically, one of the hallmarks of an imprint modification begins with changes to how DNA is decorated with small molecules called methyl groups. The pattern of methylation modulates the activity of nearby proteins, so that histones (proteins around which DNA is coiled) are chemically modified. In combination, the methyl groups and modified histones serve as a scaffold to recruit packaging proteins that either suppress or permit the activation of genes. Imprints can 
specifically target individual genes, or they can alter the activity of suites of genes that occupy a chromosomal neighborhood.

A good example of an imprinting effect is found in a mouse strain called Agouti. Strains of these mice have been isolated and in-bred to the point that siblings are essentially genetically identical. So it comes as a surprise that when you look at a litter of pups, they can look quite different. Some have an exotic coat of dark fur fringed with yellow at the tips. Other pups are much larger and yellow. The yellow pups will develop a predisposition to obesity, diabetes, and cancer, yet at the genetic level, they are identical to their smaller dark siblings (Bultman, Michaud, and Woychik 1992, Michaud et al. 1994, Morgan et al. 1999, Wolff et al. 1998). The difference lies in how the gene responsible for Agouti is decorated with methyl groups. This difference alters how the gene is packaged, and as a consequence, when and where it is active in the body. The predisposition to cancer, obesity, diabetes and a yellow coat can be altered to some extent by diet (Waterland et al. 2006). The traits are also affected by environmental contaminants, but we will return to this topic later.

\section{Prenatal Epigenetic Imprinting Changes Can Return to Haunt Individuals Late in Life}

So if imprinting affects mice, can it affect humans too? In a nutshell, yes. In a comprehensive study of a cohort born immediately following the Dutch Famine of 1944 (the Hongerwinter), interesting health patterns emerged. In the winter of 1944, occupying German forces imposed supply cuts in retaliation for a rail workers' strike. Citizens of the region suffered a precipitous decline in their daily caloric intake, but when food supplies were restored, nutritional status rebounded to near-normal conditions almost immediately. Studies of children who were gestating during this period are revealing. Only those who were nutritionally challenged during their third trimester showed a lowered birth weight. With the restoration of food supplies, they, as well as the younger first and second trimester infants grew to adulthood normally. As adults, however, it soon 
became clear that they were all predisposed to a constellation of conditions such as obesity, coronary heart disease, hypertension, elevated cholesterol, altered glucose tolerance, obstructive airways disease, and other ailments including schizophrenia and depression (Ravelli et al. 2005, Ravelli et al. 1999, Stein et al. 2007, Stein et al. 2006, Lumey et al. 2009, Lumey et al. 2007, Painter, Roseboom, and Bleker 2005, Heijmans et al. 2008). Sometimes these effects were gender-specific. For example, when the imprinting state of genetic regions associated with cardiovascular health, appetite and obesity was assessed, both males and females demonstrated altered imprinting of the cardiovascular genes (Tobi et al., 2009). However, only males showed changes in the behavior of a gene associated with appetite and glucose metabolism. Other factors that can inhibit parental nutrition, such as Crohn's and coeliac disease, in extremis might exert a similar effect to produce cleft lip and palate (Arakeri, Arali, and Brennan 2010).

The link to diet is not peculiar to starvation: tropical rainy season cycles affect food supplies, and the seasonality of conception alters resistance to disease by the time adulthood is reached (Waterland et al. 2010). Moreover, maternal obesity imparts quantifiable risks to infants (Bouchard et al. 2010). It is now known that these risks are associated with alterations to the packaging and behavior of genes. Genes such as Insulin Like Growth Factor (IGF2, which affects fetal growth, adiposity, and adult glucose tolerance), H19 (a control region adjacent to IGF2), and leptin (related to appetite, obesity and diabetes) are all affected by imprinting, and like the Agouti mice, changes in methyl group decoration of these chromosomal regions have been confirmed (Hoyo et al. 2012, Perkins et al. 2012, Guo et al. 2008, Tobi et al. 2011, Bouchard et al. 2010).

Diet is not the only factor that affects gestating humans in this way. Severe maternal depression during pregnancy can affect the imprint of a gene in the fetus (Liu et al. 2012). This latter study suggested that sensitivity to depression-induced effects might be racespecific, since African American mothers were more likely to transmit changes to their offspring than others in the cohort. While subtle genetic effects could indeed be playing a role, racial differences were not separated from cultural and dietary practices, and at the very least, we might consider that these are important confounding factors. Addictive 
substances also affect imprinting as monitored by methylation changes in both humans and rodents (D'Addario et al. 2013, Heberlein et al. 2013, Launay et al. 2009, Levine et al. 2011, Nieratschker et al. 2012, Ponomarev et al. 2012, Renthal et al. 2008, Schwarz, Hutchinson, and Bilbo 2011, Zhou et al. 2011, Murphy et al. 2012).

Contaminants in the environment can change imprinting, and the list of substances that do this ranges from endocrine disruptors leached from fungicides, insecticides, and plastics, to heavy metals (Anway et al. 2005, Anway, Leathers, and Skinner 2006, Anway and Skinner 2006, Skinner and Anway 2005, Anderson et al. 2012, Dolinoy, Huang, and Jirtle 2007, Smith and Taylor 2007, Arita and Costa 2009, Cheng, Choudhuri, and Muldoon-Jacobs 2012). The significance of this is that epigenetics appears to offer a mechanism for these compounds to alter fertility, behavior, cognition, and cancer rates. Indeed, altered imprinting is a major new subject in the study of cancer progression and treatment (Blancafort, Jin, and Frye 2013, Suva, Riggi, and Bernstein 2013, Wang and Shang 2013).

\section{Postnatal Experiences Can Install Persistent Epigenetic Changes}

In rodents, patterns of inferior maternal behavior, such as the negligent grooming of pups, affects the imprint of a gene that encodes a stress hormone receptor in the offspring. This has the effect of altering their stress response into adulthood, as well as of modifying the parental diligence and behavior that they themselves will exhibit when they become parents (Weaver et al. 2004, Weaver et al. 2005, Sapolsky 2004). The imprint status of the stress hormone receptor in offspring is transmissible to subsequent generations, but this particular imprint appears to be reversible through early fostering by good parents. Moreover, administration to the infants of a drug that alters epigenetic imprint, by nonspecifically erasing them, reverses poor parenting behavior (Weaver et al. 2005). Unfortunately, the generalized properties of the drug (trichostatin A) probably precludes routine use since it alters the imprint of other chromosomal regions indiscriminately and could activate genes better left dormant. 
Humans also exhibit imprint modifications that are associated with behavioral change. In an economically challenged Montreal district, patterns of aggressive behavior among kindergarten children were linked to heritable epigenetic changes (Provencal et al. 2013). Brain associated imprints can have even more catastrophic consequences: brain-derived neurotrophic factor (BDNF) is involved in learning, memory, and intellect, and it was discovered to be abnormally imprinted in brain samples derived from adult suicide victims (Ernst et al. 2009). Abusive experiences during childhood can leave detectable imprinting changes (McGowan et al. 2009, Labonte et al. 2012), and this has been confirmed in behavioral tests of rats as well (Roth et al. 2009). Finally, mice that have been exposed to adversity in association with a particular smell, transmit an aversion to this smell to their pups and grandpups, even if those offspring are fostered by untraumatized parents (Dias and Ressler 2014). With regard to epigenetic modification, we must infer that we are not merely passive recipients of environmental cues: we can be affected also by our behavioral interactions with it, our neighbors, and our family.

\section{Imprinting Can be Transmitted Across Generations}

Epidemiological and rodent studies have demonstrated that imprinting effects caused by diet can extend across multiple generations in humans as well. Överkalix is a northern Swedish municipality that was prone to periods of feast and famine in the late 1800 s to the early 1900s. A retrospective analysis reveals that grandchildren were predisposed to specific suites of diseases that were gender-specific in their inheritability: grandmothers could transmit disease predispositions to their granddaughters but not to their grandsons, and grandfathers could transmit to their grandsons, but not to their granddaughters (Kaati et al. 2007, Bygren, Kaati, and Edvinsson 2001, Kaati, Bygren, and Edvinsson 2002, Pembrey 2010, Pembrey et al. 2006). Trans-generational effects have since been confirmed in the Dutch famine studies (Lumey and Stein 2009), and it is a picture mirrored in rodents (Jimenez-Chillaron et al. 2009, Ng et al. 2010, Burdge et al. 2011). Imagine the legacy that starvation will impose upon the generations that emanate from 
the great famines of China (1958-61), Bangladesh (1974), Ethiopia (1983-5, 2011-13), and North Korea (1994-98)!

Similarly, imprinting alterations caused by endocrine disruptors can persist for generations (Skinner et al. 2012, Guerrero-Bosagna et al. 2013). Bisphenol A, the leachate associated with low-grade beverage containers, is an endocrine disruptor. In studies of mice (including our former example of the Agouti strain), methylation states and hence imprint status were changed by low concentrations of this contaminant (Anderson et al. 2012, Dolinoy, Huang, and Jirtle 2007). One might well imagine the paroxysm of legal activity that trans-generational effects might elicit: if the products that companies sell damage customers or bystanders slowly, perhaps even over the course of generations, how will litigation deal with the statute of limitations? This vexing question has been addressed in a provocative article where the authors examine the specific example of DES, a purported fertility drug, that had adverse trans-generational effects (Rothstein, Cai, and Marchant 2009b). If there is a little light to be had at the end of the tunnel, it is that at least some of these effects, caused either by endocrine disruptors or by nutritional challenges, are potentially reversible through changes to diet or the provision of nutritional supplements (Dolinoy, Huang, and Jirtle 2007, Dolinoy et al. 2006, Burdge et al. 2011).

\section{The Social and Ethical Challenges}

Surprisingly few people have written concerning the ethical and social ramifications of epigenetic imprinting. A notable exception to this is Rothstein, Cai, and Marchant (2009a, b), who have provided an impressively comprehensive overview of the potential ethical and legal challenges to come. Briefly, they argue that the field of epigenetics raises questions regarding environmental justice, poverty, privacy, and health. They argue persuasively that the poor are liable to suffer a disproportionate share of challenges by virtue of their constrained access to the best foods and healthcare, as well as their relegation to jurisdictions where environmental contamination, poor labor practices, and 
psychological stress will exert a pronounced effect upon them, and upon ensuing generations (Rothstein, Cai, and Marchant 2009b, a, Ziech et al. 2010). The social and racial challenges of epigenetics on a geographical scale have also been highlighted elsewhere (Guthman and Mansfield 2012, Mansfield 2012).

Somewhat more attention has been paid to risks that imprinting might pose for Assisted Reproductive Technologies (ART), otherwise known as In Vitro Fertilization (IVF). Concerns have been articulated that because imprinting changes are a normal part of egg versus sperm development, damage could be incurred during manipulation of the gametes (Johnson 2005, Kaariainen, Evers-Kiebooms, and Coviello 2005). For example, some studies suggest that the use of the (potentially immature) sperm derived for fertilization by intracellular sperm injection might predispose embryos to a suite of imprinting-related problems such as Beckwith-Weidemann, Angelman's, or Prader-Willi syndromes (Feng et al. 2011, Li et al. 2011). Despite anecdotal accounts of the aforementioned effects, preliminary studies have failed to reveal imprinting effects upon the small suit of genes analyzed (Zheng et al. 2011). However, others have argued that even a brief exposure of egg and sperm to the artificial environment of a Petri dish in a lab incubator engenders subtle risks that will only become apparent when a comprehensive analysis of the entire "epigenome" is attempted (Johnson 2005). The use of these technologies per se need not present secular ethical concerns for either reproductively challenged heterosexual couples, nor for homosexual couples potentially desiring to generate offspring from same-sex gametes, as long as the risks are known and reasonable (Testa and Harris 2004).

The major practical and ethical concern is to assure practitioners and patients alike that not only are the contributed germinal genomes undamaged, but that they are packaged to behave correctly too. As we have seen recently in world markets, pragmatism and ethics do not necessarily go hand in hand if enterprises are profit-oriented. Since assisted reproduction is provided on a for-profit basis in many countries, there are substantial impediments to assessing its procedural safety. Practices and innovations are subject to proprietary secrecy, and can vary from practice to practice. How then, does one access, compare, and evaluate medical outcomes, especially when the elements that are 
epigenetically controlled might take many years to be revealed and the medical provider meanwhile might have sold their practice or retired? It is still early days to make such a risk assessment- the first human to be born using this technology is only 30 years old...

Assisted reproductive technologies aside, the implications of epigenetics/imprinting are vast, and they are liable to reach into reproductive politics, ethics, and law in ways that we cannot presently foresee. My agenda here will be to focus upon mothers. Mothers are assumed, by virtue of the intimacy of contact with the fetus and the breastfeeding baby, to play the most significant role in nourishing and programming a child. This assumption carries risks. For example, one can imagine how popularization of this type of biological phenomena could impinge upon maternal/medical consultation, as well as upon social mores, policy, and law. Mothers could be told that their pre-conception and gestational nutritional status, habits, and exercise regimen will affect the health of their babies not only at birth, but for the rest of their lives and beyond into subsequent generations.

Smolensky argued that parents might expose themselves to liability if they were to intentionally alter pre-implantation embryos to deliver a desired trait (the example she cites is deafness) (Smolensky 2008). Although in this latter instance the manipulation envisaged was genetic, a similar argument has been advanced to suggest that liability might apply for parents who indulge in behavior that causes pre-conception epigenetic harms (Weiner 2010). As the custodian of a fetus, a woman is uniquely placed to be held accountable for what transpires during development: her feeding, behavior, and metabolic activity supports growth. Case law regarding maternal obligation has met with mixed results. In Ferguson v. City of Charleston (532 U.S. 67, 2001), pregnant women who were arrested after testing positive for the presence of drugs in their system escaped penalty since the blood tests were done without their knowledge and therefore constituted a violation of their right to freedom from arbitrary search and seizure. When the justices of the Supreme Court U.S. were considering the case, the issue of "special needs" arose. "Special needs" in this context is a category of narrowly defined circumstances where managers and employees have a duty of care to individuals or the collective: a drug-free work place is critical to their mission. For example railway, customs, and sports 
managers may require blood testing of their employees. Although the final court decision had three justices dissenting regarding the use of blood tests, "special needs," in this case the care of a fetus, were not deemed applicable by any of the adjudicators. By contrast, in Whitner $v$ South Carolina (492 S.E.2d 777 S.C., 1997), a mother failed to overturn her conviction for abusing her "viable fetus" following cocaine abuse while pregnant. In essence, personhood was extended to the fetus because the damage was inflicted during the third trimester and a baby was delivered. While most cases in this realm have had to do with physical or drug-induced harm to a fetus, it is not a stretch to wonder what the courts will make of epigenetic harms. For example, what if a mother develops an eating disorder, or decides to smoke packs of cigarette per day? Given present ambiguities regarding the concept of a "viable fetus" in some jurisdictions, there is a danger that a degree of fetal "personhood" will emerge and compete with freedoms of the mother, Roe versus Wade to the contrary. There is legitimate concern that regulations and legal precedents that develop to deal with epigenetic issues will erode the rights of the mother, potentially even prior to conception (Smith, Maccani, and Knopik 2013). Moreover, post partum deficits of attention or negligent maternal behavior could be construed to have implications that will last for generations. Will this too fall into the category of abuse?

There is a risk that the relative paucity of studies concerning paternal input into the equation could bias perceptions and drive discussions in a way that unfairly burdens preconception women, as well as mothers. While it is true that maternal imprinting and the intimacy of gestational connection means that mothers have the capacity to affect the imprint of their progeny, it is equally clear that fathers can also transmit imprints. Recent studies indicate that, depending upon the challenge or exposure, epigenetic factors are differentially packaged and delivered to the egg by human sperm (Fullston et al. 2013, Meunier et al. 2012, Rodgers et al. 2013). Moreover, post partum care and influences need not exclusively be a mother's purview, and adverse socialization can be installed by fathers as well as by mothers. For example, reading between the lines, a factor in the Montreal study of aggressive kindergarten boys was the aggressive behavior of their fathers and the consequent stress of their mothers (Hall 2014). 


\section{Proscriptive Solutions...?}

The $4^{\text {th }}$ World Conference on Women declared:

The human rights of women include their right to have control over and decide freely and responsibly on matters related to their sexuality, including sexual and reproductive health, free of coercion, discrimination and violence (Conferences 1995). (my italics)

Nevertheless, it is hard to forecast where the balance will tip with regard to state versus individual interests. With a new recognition of the role of epigenetics in reproduction, development, and aging, states will have additional incentive and interest to regulate or intervene in order to ensure generational health. One extreme possibility might be for a state to impose tax, housing, or health insurance programs that make it financially or socially difficult for a woman to do anything other than stay at home following delivery despite her desires or what her career path might optimally require. Another suggestion, already voiced, would be to level a tax on childbirth against the eventuality of epigenetic damage and consequent healthcare costs (Weiner 2010).

If mothering skills are deemed sub-par, will states find it easier to lower the threshold for removing her children to foster care? Who decides the threshold for acceptable care?

Previously, states have enacted controversial policies to move children out of their homes in the interest of either health or education: a 2002 case in the Court of Appeals in Texas upheld a decision to remove a child from her mother's care on the basis that she was failing to adequately deal with her young son's obesity (In re G.C., 66 S.W.3d 517, 524. Tex. App. Fort Worth 2002). However, the forced the removal of aboriginal children to "modern" residential schools in Canada and Australia delivered catastrophic and persistent consequences for all concerned (Australia. Human Rights and Equal Opportunity Commission. and Wilkie 1997, National Inquiry into the Separation of Aboriginal and Torres Strait Islander Children from Their Families (Australia), Wilson, and Australia. Human Rights and Equal Opportunity Commission. 1997, Elias et al. 2012). 
Exclusionary reproductive policies are not without precedent in recent memory.

In extremis, states have demonstrated a willingness to indulge in eugenics before - might there not be a temptation for totalitarian regimes to make it difficult for diabetics, former addicts, the morbidly obese, or even formerly abused citizens to have children of their own? It is not too long ago that homosexual couples were forbidden to adopt or act as custodians of children, even in states with a socialist agenda.

\section{Neutral or Disinterested Solutions}

A more contrarian perspective might be to do nothing and to assert that just as genetic variation confers resilience to our species, so too might epigenetic variation. In the premedical era, people who carried a single recessive mutation for the CFTR gene, or who were carriers of sickle cell anemia might have enjoyed resistance to cystic fibrosis or malaria respectively. By extension, perhaps epigenetic variants offer contingent protection against some future assault? Perhaps we should not work to improve the imprinting status of out compatriots? Imagine for a moment, that the 1962 Cuban Missile Crisis had escalated out of hand, and World War III had descended upon Europe. The same Dutch adults who had experienced prenatal starvation might have been well served: they would metabolize their food slightly differently, and they might possess a more generous store of fat. The result? There would be a larger portion of the general population endowed to cope with periodic deprivation. Looked at as a beneficial mechanism to contend with very real and experienced environmental conditions, epigenetics prepares the organism to cope with more of the same. That similar challenges do not repeat means that the body might be somewhat clumsy to respond to more favorable conditions.

The difference between "subliminal" gene mutations and epigenetics, is that epigenetics can respond to a challenge inside a generation and in multiple individuals. No selective breeding and proliferation of a trait is required for it to enter a population at large. But 
when peace or adequate nutrition become the norm, what are the benefits? Life for most of us unlikely to be "nasty, brutish, and short," so there is little reason to value epigenetic variation: it seems unethical to advocate for systemic and widespread social injustice on the presumption that it might husband biological variations that could prove contingently useful. On the contrary, it seems equally plausible that if governments strive to improve access to good health for their citizens, then they will be more likely both to capitalize upon opportunities, as well as to weather calamities. Invariably, there will always be individuals who chart their own course, and irrespective of what facilities a society provides for its citizens, epigenetics, like genetics, will have an ample slate of variation from which to draw when the going gets tough.

\section{Facilitative Solutions}

At the other end of the spectrum, socialist states will find it fiscally prudent, in the interest of generational health and cumulative system costs, to provide free early medical advice, nutritional supplements etc. to pre-pubescent children, to pregnant women, and to post-partum parents. Since behavioral and environmental contexts appear to influence imprinting in the young, perhaps more states will find it expedient to provide universally accessible paid parental leave, parental education, childcare facilities, enriched early childhood education programs, as well as school- and daycare- based feeding programs? Many jurisdictions have already found it practical, just, or merely expedient to support families in this way, and there was no need to invoke epigenetics to do so. What the evidence from epigenetics provides is additional incentive to regard social, environmental, and educational support in an intrinsically holistic way, rather than as an assembly of relatively disassociated but beneficial policies.

Briefly, there are two concrete examples of this philosophical disposition in modern societies. First, in Finland, the baby box program rewards prenatal medical visits with a package of baby clothing and other goodies designed to make post partum life easier. The program, begun in 1938 to address high mortality rates among the poor, was 
universalized in 1949 and persists to this day. Finland now has one of the lowest rates of infant mortality in the world. Second, in Hawaii, U.S. Centers for Disease Control-funded research provided the fodder to support a successful lawsuit that ultimately required expansion of specific health care programs. The programs in question were directed to mitigate problems arising from pregnancy, addiction, and an impoverished lifestyle/diet among a cohort of aboriginal teens. Neither program was designed to deal with epigenetic considerations, however, both go a long way to mitigating demographically significant costs, and it is easy to see how epigenetics could add weight to similar social agendas.

Finally, one wonders to what extent we will be permitted to remain private custodians of our histories. Will prospective spouses, organs of church and state, allied medical professionals, and insurers begin to demand that we disclose elements of our past that might end up costing society, if not in this generation, then the next? To what extent do individuals have to be held accountable for the choices of their ancestors, accidents of history, their medical disposition, or perhaps their errant youth? Maria Hedlund asserts that it is unfair to saddle individuals with a retrospective responsibility for their own future health nor for that of their possible descendants (Hedlund 2012). A similar dichotomy of responsibility and agency has been characterized within the context of environmental bioethics (Dupras, Ravitsky, and Williams-Jones 2012). These authors argue that a major challenge with regard to epigenetics will be to balance individual needs and rights with communitarian dictates. Some of the factors involved are clearly linked to historical social, economic, and environmental injustices over which individuals have little or no control. A subtle case in point: historically, obesity has been ascribed to over-indulgence. We now know that not only are there genetic components to the problem, but epigenetically inherited ones as well (Delport and Pollard 2010).

\section{0 . Conclusion}


In essence, what epigenetics provides is concrete evidence that confirms what we likely already know at a deeper level. Good parenting, good nutrition, a supportive culture... these are important. That the evidence might provide polemicists with ammunition to further a cause is beside the point. Good information is power, and in this case, it provides tools for transformative thinking and pro-active policy making. Perhaps uniquely, epigenetics highlights the necessity for individuals to take responsibility for themselves while also requiring governments and societies help their citizens to help themselves.

The message can be summarized:

1. Individuals owe it to themselves, to society at large, and to their prospective progeny to treat their bodies with respect.

2. Governments and societies owe it to future generations to treat their citizens with respect. Even preconception ages are susceptible to imprinting damage or improvement, and the long-term advantages and costs need to be considered.

3. The preliminary evidence suggests that imprinting is, in some cases, reversible. We are not entirely prisoners of our heritage, and we have a duty to make lifestyle improvements, if only for the sake of our descendants.

4. Even those members of society who are not reproductive have the potential and therefore the obligation to change the nutritional, educative, social, and physical environments for the better. If not for the generations to come, then for their own collective self-interest and the containment of the health and social costs that they must share.

5. Epigenetics is subtle and exerts a pervasive influence. Education of its role is key, and polemical extremes will be managed best when the stakeholders are well informed.

6. By virtue of the intimate biological connection of women with their fetuses, and because many of the studies focus upon maternal effects, there is a danger that women will be disadvantaged in the re-balancing of duties and obligations that could ensue. 
7. The scientific evidence is clear that even the pre-conceptional nutrition and behavior of prospective fathers can exert trans-generational effects upon imprinting - the obligations that attend reproductive health and child rearing are not one-sided.

8. The pervasive influence of imprinting demands integrative thinking and policies.

Forward-looking and pro-active political decisions can help to mitigate structural economic, and social inequities. An ethics that places facilitative rather than proscriptive tools in the hands of institutions and people empowered to wield them can only help to mitigate past damage and to build for a healthier future. Even if the short term cycles of democratic politics mitigate against expensive social policies in the short term, it seems likely that conversations about epigenetic features of our society will provide ample excuse to be pro-active on ethical as well as upon long-term economic grounds. This "healthier future" connotes a place where fewer resources would be expended addressing at least some of the complex health, behavioral, and social problems that afflict our times. By the same token, as individuals, we owe it to our own comfort and vitality in older age, as well as to our offspring, to exercise discipline and sense in the care of ourselves. Responsibility for epigenetic heath is a two way street - it is a collective and personal obligation.

\section{Acknowledgements}

MJC was supported by a grant for the Natural Sciences and Engineering Research Council of Canada.

\section{References}

Anderson, O. S., M. S. Nahar, C. Faulk, T. R. Jones, C. Liao, K. Kannan, C. Weinhouse, L. S. Rozek, and D. C. Dolinoy. 2012. "Epigenetic responses following maternal 
dietary exposure to physiologically relevant levels of bisphenol A." Environ Mol Mutagen 53 (5):334-42.

Anway, M. D., A. S. Cupp, M. Uzumcu, and M. K. Skinner. 2005. "Epigenetic transgenerational actions of endocrine disruptors and male fertility." Science 308 (5727):1466-9.

Anway, M. D., C. Leathers, and M. K. Skinner. 2006. "Endocrine disruptor vinclozolin induced epigenetic transgenerational adult-onset disease." Endocrinology 147 (12):5515-23.

Anway, M. D., and M. K. Skinner. 2006. "Epigenetic transgenerational actions of endocrine disruptors." Endocrinology 147 (6 Suppl):S43-9.

Arakeri, G., V. Arali, and P. A. Brennan. 2010. "Cleft lip and palate: an adverse pregnancy outcome due to undiagnosed maternal and paternal coeliac disease." Med Hypotheses 75 (1):93-8.

Arita, A., and M. Costa. 2009. "Epigenetics in metal carcinogenesis: nickel, arsenic, chromium and cadmium." Metallomics 1 (3):222-8.

Australia. Human Rights and Equal Opportunity Commission., and Meredith Wilkie. 1997. Bringing them home: report of the national inquiry into the separation of Aboriginal and Torres Strait Islander children from their families, Parliamentary paper,. Sydney: Human Rights and Equal Opportunity Commission.

Blancafort, P., J. Jin, and S. Frye. 2013. "Writing and rewriting the epigenetic code of cancer cells: from engineered proteins to small molecules." Mol Pharmacol 83 (3):563-76.

Bouchard, L., S. Thibault, S. P. Guay, M. Santure, A. Monpetit, J. St-Pierre, P. Perron, and D. Brisson. 2010. "Leptin gene epigenetic adaptation to impaired glucose metabolism during pregnancy." Diabetes Care 33 (11):2436-41.

Bultman, S.J., E.J. Michaud, and R.P. Woychik. 1992. "Molecular characterization of the mouse Agouti locus." Cell 71:1195-1204.

Burdge, G. C., S. P. Hoile, T. Uller, N. A. Thomas, P. D. Gluckman, M. A. Hanson, and K. A. Lillycrop. 2011. "Progressive, transgenerational changes in offspring phenotype and epigenotype following nutritional transition." PLoS One 6 (11):e28282.

Bygren, L. O., G. Kaati, and S. Edvinsson. 2001. "Longevity determined by paternal ancestors' nutrition during their slow growth period." Acta Biotheor 49 (1):53-9.

Cheng, T. F., S. Choudhuri, and K. Muldoon-Jacobs. 2012. "Epigenetic targets of some toxicologically relevant metals: a review of the literature." J Appl Toxicol 32 (9):643-53.

Conferences, United Nations Specialised. 1995. Beijing Declaration and Platform for Action, adopted at the Fourth World Conference on Women. edited by United Nations.

D'Addario, C., F. F. Caputi, T. J. Ekstrom, M. Di Benedetto, M. Maccarrone, P. Romualdi, and S. Candeletti. 2013. "Ethanol induces epigenetic modulation of prodynorphin and pronociceptin gene expression in the rat amygdala complex." J Mol Neurosci 49 (2):312-9. 
Delport, Tiffany, and Irina Pollard. 2010. "Changing perspective on obesity: genetic and environmental health consequences in the offspring." Eubios Journal of Asian and International Bioethics 20 (6):170-173.

Dias, B. G., and K. J. Ressler. 2014. "Parental olfactory experience influences behavior and neural structure in subsequent generations." Nat Neurosci 17:86-96.

Dolinoy, D. C., D. Huang, and R. L. Jirtle. 2007. "Maternal nutrient supplementation counteracts bisphenol A-induced DNA hypomethylation in early development." Proc Natl Acad Sci U S A 104 (32):13056-61.

Dolinoy, D. C., J. R. Weidman, R. A. Waterland, and R. L. Jirtle. 2006. "Maternal genistein alters coat color and protects Avy mouse offspring from obesity by modifying the fetal epigenome." Environ Health Perspect 114 (4):567-72.

Dupras, C., V. Ravitsky, and B. Williams-Jones. 2012. "Epigenetics and the Environment in Bioethics." Bioethics.

Elias, B., J. Mignone, M. Hall, S. P. Hong, L. Hart, and J. Sareen. 2012. "Trauma and suicide behaviour histories among a Canadian indigenous population: an empirical exploration of the potential role of Canada's residential school system." Soc Sci Med 74 (10):1560-9.

Ernst, C., V. Deleva, X. Deng, A. Sequeira, A. Pomarenski, T. Klempan, N. Ernst, R. Quirion, A. Gratton, M. Szyf, and G. Turecki. 2009. "Alternative splicing, methylation state, and expression profile of tropomyosin-related kinase B in the frontal cortex of suicide completers." Arch Gen Psychiatry 66 (1):22-32.

Feng, C., S. Tian, Y. Zhang, J. He, X. M. Zhu, D. Zhang, J. Z. Sheng, and H. F. Huang. 2011. "General imprinting status is stable in assisted reproduction-conceived offspring." Fertil Steril 96 (6):1417-1423 e9.

Fullston, T., E. M. Ohlsson Teague, N. O. Palmer, M. J. DeBlasio, M. Mitchell, M. Corbett, C. G. Print, J. A. Owens, and M. Lane. 2013. "Paternal obesity initiates metabolic disturbances in two generations of mice with incomplete penetrance to the F2 generation and alters the transcriptional profile of testis and sperm microRNA content." FASEB J 27 (10):4226-43.

Guerrero-Bosagna, C., M. Savenkova, M. M. Haque, E. Nilsson, and M. K. Skinner. 2013. "Environmentally induced epigenetic transgenerational inheritance of altered Sertoli cell transcriptome and epigenome: molecular etiology of male infertility." PLoS One 8 (3):e59922.

Guo, L., S. Choufani, J. Ferreira, A. Smith, D. Chitayat, C. Shuman, R. Uxa, S. Keating, J. Kingdom, and R. Weksberg. 2008. "Altered gene expression and methylation of the human chromosome 11 imprinted region in small for gestational age (SGA) placentae." Dev Biol 320 (1):79-91.

Guthman, Julie, and Becky Mansfield. 2012. "The implications of environmental epigenetics: a new direction for geographic inquiry on health, space, and nature-society relations." Progress in Human Geography 37 (4):486-504.

Hall, S. S. 2014. "Behaviour and biology: The accidental epigeneticist." Nature 505 (7481):14-7. Heberlein, A., M. Muschler, H. Frieling, M. Behr, C. Eberlein, J. Wilhelm, M. Groschl, J. Kornhuber, S. Bleich, and T. Hillemacher. 2013. "Epigenetic down regulation of nerve growth factor during alcohol withdrawal." Addict Biol 18 (3):508-10.

Hedlund, Maria. 2012. "Epigenetic Responsibility." Medicine Studies 3:171-183. 
Heijmans, B. T., E. W. Tobi, A. D. Stein, H. Putter, G. J. Blauw, E. S. Susser, P. E. Slagboom, and L. H. Lumey. 2008. "Persistent epigenetic differences associated with prenatal exposure to famine in humans." Proc Natl Acad Sci U $S$ A 105 (44):17046-9.

Hoyo, C., K. Fortner, A. P. Murtha, J. M. Schildkraut, A. Soubry, W. DemarkWahnefried, R. L. Jirtle, J. Kurtzberg, M. R. Forman, F. Overcash, Z. Huang, and S. K. Murphy. 2012. "Association of cord blood methylation fractions at imprinted insulin-like growth factor 2 (IGF2), plasma IGF2, and birth weight." Cancer Causes Control 23 (4):635-45.

Jimenez-Chillaron, J. C., E. Isganaitis, M. Charalambous, S. Gesta, T. Pentinat-Pelegrin, R. R. Faucette, J. P. Otis, A. Chow, R. Diaz, A. Ferguson-Smith, and M. E. Patti. 2009. "Intergenerational transmission of glucose intolerance and obesity by in utero undernutrition in mice." Diabetes 58 (2):460-8.

Johnson, M. H. 2005. "The problematic in-vitro embryo in the age of epigenetics." Reprod Biomed Online 10 Suppl 1:88-96.

Kaariainen, H., G. Evers-Kiebooms, and D. Coviello. 2005. "Medically assisted reproduction and ethical challenges." Toxicol Appl Pharmacol 207 (2 Suppl):684-8.

Kaati, G., L. O. Bygren, and S. Edvinsson. 2002. "Cardiovascular and diabetes mortality determined by nutrition during parents' and grandparents' slow growth period." Eur J Hum Genet 10 (11):682-8.

Kaati, G., L. O. Bygren, M. Pembrey, and M. Sjostrom. 2007. "Transgenerational response to nutrition, early life circumstances and longevity." Eur J Hum Genet 15 (7):784-90.

Labonte, B., M. Suderman, G. Maussion, L. Navaro, V. Yerko, I. Mahar, A. Bureau, N. Mechawar, M. Szyf, M. J. Meaney, and G. Turecki. 2012. "Genome-wide epigenetic regulation by early-life trauma." Arch Gen Psychiatry 69 (7):72231.

Launay, J. M., M. Del Pino, G. Chironi, J. Callebert, K. Peoc'h, J. L. Megnien, J. Mallet, A. Simon, and F. Rendu. 2009. "Smoking induces long-lasting effects through a monoamine-oxidase epigenetic regulation." PLoS One 4 (11):e7959.

Levine, A., Y. Huang, B. Drisaldi, E. A. Griffin, Jr., D. D. Pollak, S. Xu, D. Yin, C. Schaffran, D. B. Kandel, and E. R. Kandel. 2011. "Molecular mechanism for a gateway drug: epigenetic changes initiated by nicotine prime gene expression by cocaine." Sci Transl Med 3 (107):107ra109: 1-10.

Li, L., L. Wang, X. Xu, H. Lou, F. Le, J. Sheng, H. Huang, and F. Jin. 2011. "Genome-wide DNA methylation patterns in IVF-conceived mice and their progeny: a putative model for ART-conceived humans." Reprod Toxicol 32 (1):98-105.

Lumey, L. H., and A. D. Stein. 2009. "Transgenerational effects of prenatal exposure to the Dutch famine." BJOG 116 (6):868; author reply 868.

Lumey, L. H., A. D. Stein, H. S. Kahn, and J. A. Romijn. 2009. "Lipid profiles in middleaged men and women after famine exposure during gestation: the Dutch Hunger Winter Families Study." Am J Clin Nutr 89 (6):1737-43.

Lumey, L. H., A. D. Stein, H. S. Kahn, K. M. van der Pal-de Bruin, G. J. Blauw, P. A. Zybert, and E. S. Susser. 2007. "Cohort profile: the Dutch Hunger Winter families study." Int J Epidemiol 36 (6):1196-204. 
Mansfield, Becky. 2012. "Race and the new epigenetic biopolitics of environmental health." Biosocieties 7 (4):353-72. d

McGowan, P. O., A. Sasaki, A. C. D'Alessio, S. Dymov, B. Labonte, M. Szyf, G. Turecki, and M. J. Meaney. 2009. "Epigenetic regulation of the glucocorticoid receptor in human brain associates with childhood abuse." Nat Neurosci 12 (3):342-8.

Meunier, L., B. Siddeek, A. Vega, N. Lakhdari, L. Inoubli, R. P. Bellon, G. Lemaire, C. Mauduit, and M. Benahmed. 2012. "Perinatal programming of adult rat germ cell death after exposure to xenoestrogens: role of microRNA miR-29 family in the down-regulation of DNA methyltransferases and Mcl-1." Endocrinology 153 (4):1936-47.

Michaud, E. J., M. J. van Vugt, S. J. Bultman, H. O. Sweet, M. T. Davisson, and R. P. Woychik. 1994. "Differential expression of a new dominant agouti allele (Aiapy) is correlated with methylation state and is influenced by parental lineage." Genes Dev 8 (12):1463-72.

Moore, T., and D. Haig. 1991. "Genomic imprinting in mammalian development: a parental tug-of-war." Trends Genet 7 (2):45-9.

Morgan, H. D., H. G. Sutherland, D. I. Martin, and E. Whitelaw. 1999. "Epigenetic inheritance at the agouti locus in the mouse." Nat Genet 23 (3):314-8.

Murphy, S. K., A. Adigun, Z. Huang, F. Overcash, F. Wang, R. L. Jirtle, J. M. Schildkraut, A. P. Murtha, E. S. Iversen, and C. Hoyo. 2012. "Gender-specific methylation differences in relation to prenatal exposure to cigarette smoke."

National Inquiry into the Separation of Aboriginal and Torres Strait Islander Children from Their Families (Australia), Ronald Wilson, and Australia. Human Rights and Equal Opportunity Commission. 1997. Bringing them home : a guide to the findings and recommendations of the National Inquiry into the Separation of Aboriginal and Torres Strait Islander Children from Their Families. Sydney: Human Rights and Equal Opportunity Commission.

Ng, S. F., R. C. Lin, D. R. Laybutt, R. Barres, J. A. Owens, and M. J. Morris. 2010. "Chronic high-fat diet in fathers programs beta-cell dysfunction in female rat offspring." Nature 467 (7318):963-6.

Nieratschker, V., M. Grosshans, J. Frank, J. Strohmaier, C. von der Goltz, O. El-Maarri, S. H. Witt, S. Cichon, M. M. Nothen, F. Kiefer, and M. Rietschel. 2012. "Epigenetic alteration of the dopamine transporter gene in alcoholdependent patients is associated with age." Addict Biol.

Painter, R. C., T. J. Roseboom, and O. P. Bleker. 2005. "Prenatal exposure to the Dutch famine and disease in later life: an overview." Reprod Toxicol 20 (3):345-52.

Pembrey, M. E. 2010. "Male-line transgenerational responses in humans." Hum Fertil (Camb) 13 (4):268-71.

Pembrey, M. E., L. O. Bygren, G. Kaati, S. Edvinsson, K. Northstone, M. Sjostrom, and J. Golding. 2006. "Sex-specific, male-line transgenerational responses in humans." Eur J Hum Genet 14 (2):159-66.

Perkins, E., S. K. Murphy, A. P. Murtha, J. Schildkraut, R. L. Jirtle, W. DemarkWahnefried, M. R. Forman, J. Kurtzberg, F. Overcash, Z. Huang, and C. Hoyo. 2012. "Insulin-like growth factor 2/H19 methylation at birth and risk of overweight and obesity in children." J Pediatr 161 (1):31-9. 
Ponomarev, I., S. Wang, L. Zhang, R. A. Harris, and R. D. Mayfield. 2012. "Gene coexpression networks in human brain identify epigenetic modifications in alcohol dependence." J Neurosci 32 (5):1884-97. doi: 32/5/1884 [pii] 10.1523/JNEUROSCI.3136-11.2012.

Provencal, N., M. J. Suderman, D. Caramaschi, D. Wang, M. Hallett, F. Vitaro, R. E. Tremblay, and M. Szyf. 2013. "Differential DNA methylation regions in cytokine and transcription factor genomic loci associate with childhood physical aggression." PLoS One 8 (8):e71691.

Ravelli, A. C., O. P. Bleker, T. J. Roseboom, G. A. van Montfrans, C. Osmond, and D. J. Barker. 2005. "Cardiovascular disease in survivors of the Dutch famine." Nestle Nutr Workshop Ser Pediatr Program 55:183-91; discussion 191-5.

Ravelli, A. C., J. H. van Der Meulen, C. Osmond, D. J. Barker, and O. P. Bleker. 1999. "Obesity at the age of $50 \mathrm{y}$ in men and women exposed to famine prenatally." Am J Clin Nutr 70 (5):811-6.

Renthal, W., T. L. Carle, I. Maze, H. E. Covington, 3rd, H. T. Truong, I. Alibhai, A. Kumar, R. L. Montgomery, E. N. Olson, and E. J. Nestler. 2008. "Delta FosB mediates epigenetic desensitization of the c-fos gene after chronic amphetamine exposure." J Neurosci 28 (29):7344-9.

Rodgers, A. B., C. P. Morgan, S. L. Bronson, S. Revello, and T. L. Bale. 2013. "Paternal stress exposure alters sperm microRNA content and reprograms offspring HPA stress axis regulation." J Neurosci 33 (21):9003-12.

Roth, T. L., F. D. Lubin, A. J. Funk, and J. D. Sweatt. 2009. "Lasting epigenetic influence of early-life adversity on the BDNF gene." Biol Psychiatry 65 (9):760-9.

Rothstein, M. A., Y. Cai, and G. E. Marchant. 2009a. "Ethical implications of epigenetics research." Nat Rev Genet 10 (4):224.

Rothstein, M. A., Y. Cai, and G. E. Marchant. 2009b. "The ghost in our genes: legal and ethical implications of epigenetics." Health Matrix Clevel 19 (1):1-62.

Sapolsky, R. M. 2004. "Mothering style and methylation." Nat Neurosci 7 (8):791-2.

Schwarz, J. M., M. R. Hutchinson, and S. D. Bilbo. 2011. "Early-life experience decreases drug-induced reinstatement of morphine CPP in adulthood via microglial-specific epigenetic programming of anti-inflammatory IL-10 expression." J Neurosci 31 (49):17835-47.

Skinner, M. K., and M. D. Anway. 2005. "Seminiferous cord formation and germ-cell programming: epigenetic transgenerational actions of endocrine disruptors." Ann N Y Acad Sci 1061:18-32.

Skinner, M. K., M. Mohan, M. M. Haque, B. Zhang, and M. I. Savenkova. 2012.

"Epigenetic transgenerational inheritance of somatic transcriptomes and epigenetic control regions." Genome Biol 13 (10):R91.

Smith, C. C., and H. S. Taylor. 2007. "Xenoestrogen exposure imprints expression of genes (Hoxa10) required for normal uterine development." FASEB J 21 (1):239-46.

Smith, T. F., M. A. Maccani, and V. S. Knopik. 2013. "Maternal Smoking During Pregnancy and Offspring Health Outcomes: The Role of Epigenetic Research in Informing Legal Policy and Practice." Hastings Law Journal 64 (6):16191648. 
Smolensky, K. R. 2008. "Creating Children with Disabilities: Parental Tort Liability for Preimplantation Genetic Interventions." Hastings Law Journal 60 (2):299345.

Stein, A. D., H. S. Kahn, A. Rundle, P. A. Zybert, K. van der Pal-de Bruin, and L. H. Lumey. 2007. "Anthropometric measures in middle age after exposure to famine during gestation: evidence from the Dutch famine." Am J Clin Nutr 85 (3):869-76.

Stein, A. D., P. A. Zybert, K. van der Pal-de Bruin, and L. H. Lumey. 2006. "Exposure to famine during gestation, size at birth, and blood pressure at age $59 \mathrm{y}$ : evidence from the Dutch Famine." Eur J Epidemiol 21 (10):759-65.

Suva, M. L., N. Riggi, and B. E. Bernstein. 2013. "Epigenetic reprogramming in cancer." Science 339 (6127):1567-70.

Testa, G., and J. Harris. 2004. "Genetics. Ethical aspects of ES cell-derived gametes." Science 305 (5691):1719.

Tobi, E. W., B. T. Heijmans, D. Kremer, H. Putter, H. A. Delemarre-van de Waal, M. J. Finken, J. M. Wit, and P. E. Slagboom. 2011. "DNA methylation of IGF2, GNASAS, INSIGF and LEP and being born small for gestational age." Epigenetics 6 (2):171-6.

van Heyningen, Veronica. 2000. "Gene games of the future." Nature 408 (6814):769771.

Wang, Y., and Y. Shang. 2013. "Epigenetic control of epithelial-to-mesenchymal transition and cancer metastasis." Exp Cell Res 319 (2):160-9.

Waterland, R. A., D. C. Dolinoy, J. R. Lin, C. A. Smith, X. Shi, and K. G. Tahiliani. 2006. "Maternal methyl supplements increase offspring DNA methylation at Axin Fused." Genesis 44 (9):401-6..

Waterland, R. A., R. Kellermayer, E. Laritsky, P. Rayco-Solon, R. A. Harris, M. Travisano, W. Zhang, M. S. Torskaya, J. Zhang, L. Shen, M. J. Manary, and A. M. Prentice. 2010. "Season of conception in rural gambia affects DNA methylation at putative human metastable epialleles." PLoS Genet 6 (12):e1001252.

Weaver, I. C., N. Cervoni, F. A. Champagne, A. C. D'Alessio, S. Sharma, J. R. Seckl, S. Dymov, M. Szyf, and M. J. Meaney. 2004. "Epigenetic programming by maternal behavior." Nat Neurosci 7 (8):847-54.

Weaver, I. C., F. A. Champagne, S. E. Brown, S. Dymov, S. Sharma, M. J. Meaney, and M. Szyf. 2005. "Reversal of maternal programming of stress responses in adult offspring through methyl supplementation: altering epigenetic marking later in life." J Neurosci 25 (47):11045-54.

Weiner, Christopher J. 2010. "Transgenerational Tort Liability for Epigenetic Disease." DePaul J. Health Care L. 13:319-338.

Wilkins, J. F., and D. Haig. 2003. "What good is genomic imprinting: the function of parent-specific gene expression." Nat Rev Genet 4 (5):359-68.

Wolff, G. L., R. L. Kodell, S. R. Moore, and C. A. Cooney. 1998. "Maternal epigenetics and methyl supplements affect agouti gene expression in Avy/a mice." FASEB $J 12$ (11):949-57.

Zheng, H. Y., X. Y. Shi, L. L. Wang, Y. Q. Wu, S. L. Chen, and L. Zhang. 2011. "Study of DNA methylation patterns of imprinted genes in children born after assisted 
reproductive technologies reveals no imprinting errors: A pilot study." Exp Ther Med 2 (4):751-755.

Zhou, Z., Q. Yuan, D. C. Mash, and D. Goldman. 2011. "Substance-specific and shared transcription and epigenetic changes in the human hippocampus chronically exposed to cocaine and alcohol." Proc Natl Acad Sci U S A 108 (16):6626-31.

Ziech, D., R. Franco, A. Pappa, V. Malamou-Mitsi, S. Georgakila, A. G. Georgakilas, and M. I. Panayiotidis. 2010. "The role of epigenetics in environmental and occupational carcinogenesis." Chem Biol Interact 188 (2):340-9. 